\title{
Closing the Arab Democratic Gap : A Re-Assessment of the Tunisian Democratic Transition
}

\author{
Yolaine Frossard de Saugy", McGill University
}

\begin{abstract}
Tunisia is often described as the outlier of the Arab Spring, the one case in which a form of political transition decidedly happened. The fact that this transition first led to the rule of the Islamist party Ennahda has reignited long-standing debates on the role of Islam in politics, the relationship between religion and democracy, and the consequences of their potential incompatibility for the future of Tunisian democracy. A sizeable literature has attempted to address these topics over the years, but it is of little help when trying to understand the events of the Arab Spring and the Tunisian transition, especially when it comes to their impact on the Islamist parties themselves. Borrowing from Villalón's study of Islam and politics in sub-Saharan Africa, this paper argues that, instead of considering whether Tunisian actors fit within a preconceived notion of democracy, we should consider the process of political bargaining itself as democratic; focusing on the substance of democracy rather than its form sheds new light on the Tunisian case and helps explain various outcomes including the progressive liberalization of Islamist parties and the gradual but distinctive flourishing of democracy in the Tunisian context.
\end{abstract}

Keywords: Democratic Transition, Tunisia, Islam

\section{Résumé}

La Tunisie est souvent décrite comme le cas aberrant du Printemps arabe, le seul cas où une forme de transition politique s'est résolument produite. Le fait que cette transition ait d'abord mené à la prise du pouvoir du parti islamiste Ennahda a relancé les débats de longue date sur le rôle de l'Islam en politique, la relation entre religion et démocratie et les conséquences de leur incompatibilité potentielle pour l'avenir de la démocratie tunisienne. Une littérature considérable a tenté d'aborder ce sujet au fil des années, mais elle ne permet pas vraiment de comprendre les événements du Printemps arabe et de la transition tunisienne, et ce, surtout lorsqu'il s'agit de leur impact sur les partis islamistes euxmêmes. S'inspirant de l'étude de Villalón sur l'Islam et la politique en Afrique subsaharienne, cet article soutient qu'au lieu de considérer si les acteurs tunisiens s'inscrivent dans une notion préconçue de la démocratie, nous devrions considérer le processus de marchandage politique lui-même comme démocratique; se concentrer sur l'essence de la démocratie plutôt que sur sa forme jette un éclairage différent sur le cas tunisien et permet d'expliquer différents résultats, notamment la libéralisation progressive des partis islamistes et l'épanouissement graduel mais particulier de la démocratie dans le contexte tunisien.

Mots-clés : Transition démocratique, Tunisie, Islam

\footnotetext{
*Biography:

Yolaine Frossard de Saugy is a PhD candidate in international relations and comparative politics at McGill University. She specializes in questions of global health governance and HIVIAIDS policy, key populations and minority rights, and African politics, regimes and colonial legacies. She holds an MSc in African Politics from SOAS, University of London, and an MA in International History from the Graduate Institute of International and Development Studies, Geneva.

Biographie :

Yolaine Frossard de Saugy est doctorante en relations internationales et politique comparée à l'Université McGill. Elle se spécialise dans les questions de gouvernance mondiale de la santé et de politiques sur le VIH/sida, les populations clés et les droits des minorités ainsi que la politique africaine et les régimes et héritages coloniaux. Elle est titulaire d'une maîtrise en politique africaine de l'Université de Londres (SOAS) et d'une maîtrise en histoire internationale de l'Institut de hautes études internationales et du développement à Genève.
} 


\section{Introduction}

Tunisia is often considered the only country to have rather successfully transitioned from authoritarianism to democracy after the Arab Spring, but even with this distinction many have long remained cautious about its political prospects. One factor seemed to crystallize most concerns in the early years of the transition: the prominence of Islamist movements. For many this was a worrying sign, an attitude reinforced by a sizeable literature devoted to the possible incompatibility of Islam and democracy, and the questionable potential of Islamist movements for moderation - whatever this is taken to mean.

This paper argues that these questions were mis-framed and led to biased assessments of the Tunisian democratization process; relying on the framework put forward by Leonardo Villalón to study the democratic transition of Muslim-majority countries in sub-Saharan Africa, this study shows that Tunisia followed a path on which religious forces were instrumental in shaping, but not determining, political outcomes, and should thus have been evaluated without assumptions about their nature. This is not to say that religion did not play a role in Tunisian politics, to the contrary; but Villalón's framework, by showing the rise of religious forces as an outcome of, not a threat to, the liberalization process, and conceptualizing democracy as a practice, allows us to evaluate the Tunisian transition on its own merit - and to better understand the role of religious movements in it.

This study draws on secondary sources to analyze key moments of the transition such as the 2011 constituent assembly election, the constitutional process, and the 2014 election, at the end of which Tunisia seemed to have "met the four standard conditions for a completed democratic transition" (Stepan, 2018b, p.43). This choice of sources was guided by the fact that the main claim of the analysis is that the Tunisian democratization process has been misunderstood, which can be demonstrated without adding new empirical evidence to the already numerous accounts of the events. An overview of the 2011-2014 period through the existing literature provides sufficient material to evaluate whether the key predictions of the Villalón model - the rise of religion in politics, the democratization of religious movements, and the key role of bargaining and negotiation - were realized in the case of Tunisia. If so, through the redefinition of democracy as practice, it will allow us to challenge the trope of the Arab/Muslim democratic deficit and question the nature of democracy in comparative politics approaches. The aim of this research is therefore not to simply generalize Villalón's framework but to explore the challenges it poses to most of the scholarship on Islam and politics as well as the ways in which it can help us re-think the meaning and impact of democracy in Tunisia and in the Arab world. This will be done by first turning to previous theoretical approaches of democratization in the Middle East, then applying Villalón's framework to the Tunisian case, before considering limits to the model, in the case of Tunisia as well as more widely.

A few definitional issues need to be addressed: what constitutes secularist or Islamist movements has often been debated and the terms have been applied to groups that have very little in common. In this paper secularism will be used to define groups that understand themselves as such, which in the case of Tunisia often means a French-style laïcité but stops short of the state control of religion imposed by some authoritarian regimes in the region. The term Islamist will be used in the sense of a political ideology centered on Islam as the organizing force of society and politics. It should also be noted that most of the names of people and movements translated from Arabic have a wide range of spellings in English, depending on the authors; for ease of reading one will be use consistently except when quoting scholars who have chosen alternative spellings.

\section{Islam and Governance in the Middle East: Theoretical Perspectives}

\section{Islam and Democracy: A Complicated History}

To state that the study of democracy in the Muslim world has been controversial is a euphemism. As noted by Stepan, most literature on democratization does not take into account Muslim countries: none of the major studies such as O'Donnell's use them as cases, and the most prominent text on the topic remains Huntington's infamous assertion of the incompatibility of Islam and democracy (Stepan 2018a). This question has marked most of the scholarship on the topic, which 
has traditionally been divided into two camps: the first, comprised of Huntington's fellows such as Lewis, Gellner, or Ajmi, saw Muslim societies as shaped by an essential set of beliefs which made them fundamentally resistant to the modernization that democracy purportedly represents (Hashemi, 2013). The other, rising in reaction to this essentialist view, has attempted to show that Islam actually is compatible with democracy or that its core tenets constitute a viable basis for democratization (Kadivar, 2018; Villalón, 2010).

The terms of the debate have tended to revolve around the notion of compatibility on both sides. The Oxford Handbook of Islam and Politics itself approached the topic in this manner, referring to a Freedom House report entitled "Islamic World's Democracy Deficit" as evidence that some credence should be given to the idea that there is a specific issue in Muslim-majority countries when it comes to democracy, (Hashemi 2013). Dorraj, though exploring in depth the role and meaning of democracy in Islam, still framed his approach in terms of compatibility as well (Dorraj, 1999), as did Cesari even when she stated that secularism was not necessarily part of the "minimal democratic 'kit"' (Cesari, 2014, p. 264). Some have attempted to qualify this notion, alleging that the evidence might point more to an Arab than a Muslim "democratic gap", but the fundamental assumption remained unchallenged (Villalón, 2010).

Indeed, even authors who denounced the existing discourses fell into the compatibility trap: Stepan, who called for the acknowledgement of the multivocality of religion and the possibility of different forms of democracy obtained through local negotiations, ultimately framed his argument in terms of the compatibility of Islam and democracy nonetheless (Stepan, 2012); Bayat, who similarly denounced the view of Muslim societies as uniform and convincingly argued that local contexts and practices must be taken into account to understand the variation in political outcomes, concluded that "the question is not whether Islam is or is not compatible with democracy [...] but rather under what conditions Muslims can make them compatible" (Bayat, 2007, p.10, emphasis in the original). Though they acknowledged the possibility of Muslim democracy, these authors could not escape the initial assumption that there is something distinctive about Islam that should be considered first when attempting to understand political outcomes ${ }^{1}$.

It must be mentioned that these shortcomings have not gone completely unnoticed: Sadowski already criticized them in 1997, albeit without offering much of an answer beyond a shift to the study of "the forces that promote or retard" democratization (Sadowski, 1997, p. 43). Others have taken more convincing steps to escape from the incompatibility/compatibility trap by following, or anticipating, Villalón's focus on the democratic process and its unfolding. Drumberg, for instance, insisted on the multi-level logic of democratization and the structural conditions of authoritarian regimes to explain the shaping of political transitions, instead of the nature of the social actors involved (Drumberg, 2014); Esposito, Sonn and Voll also called for a "more nuanced understanding of democracy" focusing on "the effectiveness of the democratic process" (Esposito et al., 2016, p. 201). The most thorough study of the implications of this shift came from Otayek and Soares, who theorized the rise of religious forces in democratizing settings but explicitly restrained their study to sub-Saharan Africa (Otayek and Soares, 2007).

Thus, even though the Arab Spring has reignited a debate that had already been fueled by the events of 9/11, in the Middle East democracy often remained conceptualized as a fully formed concept exported and implanted, successfully or not depending on the perspectives, in Muslim societies.

\section{Islamist Movements and the Moderation Question}

\footnotetext{
1 Interestingly, sometimes these assumptions can be corrected by the very data these researchers use: Rahman conducted a quantitative analysis of the role of institutionalized religion on political outcomes in Muslim countries under the assumption that findings would corroborate the compatibility hypothesis, but could not make his data cooperate and had to conclude that "the absence of an effect of all three measures of state-institutionalized Islam on regime type suggests that the incorporation of Islam into the state's political and legal structure does not significantly influence a state's political trajectory" (Rahman, 2013, p. 569); the presence of oil, belonging to the MENA region, and communist legacies appeared as better predictors of regime type than Islam.
} 
A second question that has been raised is the role of Islamist movements in the democratic process. Some of the discussions on the topic have been plagued by the same issues as those on Islam, with much energy focused on determining whether Islamist movements could be trusted to play the democratic game or inevitably had ulterior motives such as the establishment of a theocracy (Netterstrøm, 2015). For some the question was preemptively solved, and there was no doubt that all Islamist movements could be collapsed into a single category of actors seeking to establish an Islamic state, however gradually (Alvi, 2019; Hamid, 2014; Martinez Fuentes, 2017). Others have nonetheless heeded the call to move away from these assumptions to study the realities of Islamic movements' political practices and their consequences in less pessimistic and predetermined terms (Dalmasso and Cavatorta, 2013).

Studies interrogating the role of Islamist movements in the political sphere have tended to focus first on the movements themselves and their internal workings, and then on the role of their respective contexts; the key trend was to consider that "under the appropriate institutional conditions, Islamists can and do strategically moderate their ideologies and play a role in democratic reform" (Brynen et al., 2012, pp. 121-2). This "moderation-inclusion" paradigm relied on three core mechanisms: the role of electoral incentives, institutional structures (Islamist movements engaging in the democratic process needed to shift their resources to traditional political activities, which led to moderation), and the "pothole theory of democracy" - the idea that once in power, the need to take care of daily life issues relegated ideology to the back burner (Brynen et al., 2012, pp 121-2). Others have emphasized the influence of political learning, with democratic structures creating an incentive for more cooperation which ultimately led to moderation, or a shift in the boundaries of what constituted justifiable action through internal debates, but ultimately the overall logic held: a shift in practice came first, and in thinking second. Though this approach had the merit of treating Islamists as rational actors, it raised some questions: not only did it leave open the issue of why practices would shift in the first place, it also did not interrogate the normative biases that undergird the notion of moderation (Netterstrøm, 2015). In addition, these studies tended to distinguish between tactical moderation and ideological moderation, with the implication that the latter was the only true way to moderate when pragmatism was only temporary and superficial. This fell under the fallacy of the hidden agenda and ignored the fact that tactical concessions can bring about ideological shifts over time, or that power can also constitute an end in itself for these movements rather than the means to an ulterior goal. Finally, this debate also fell into the biases of the compatibility trap, albeit in a new way, by assuming that democracy happened first and Islamists engaged in it afterwards, rather than considering the idea that they could be an integral part of the democratization process (Marzo, 2018).

Some have attempted to qualify these views, by emphasizing the diversity of Islamist movements and the need to consider each of them separately, rather than as a unified category that obscures local trends (Esposito et al., 2018; Sadiki, 2018). Indeed, in some cases exclusion rather than inclusion has been viewed as the cause of moderation: Cavatorta and Merone argue that state repression and social isolation led Tunisia's Islamist party Ennahda toward more moderate positions before the revolution, making it a regional exception (Cavatorta and Merone, 2013). Others have also highlighted the fact that a priori assumptions about the nature of Islamist politics mean that researchers often failed to interrogate the role of secular parties and their potential refusal to compromise or moderate as well (Marks, 2018); indeed, in the Middle East secular forces have often proven to be the undemocratic and repressive ones, and focusing on the nature of the social forces as the primary cause of political outcomes instead of privileging the process itself often obscured the actual unfolding of events (Marzo, 2018). These calls, though promising, have unfortunately remained few and far between. The Arab Spring has led to renewed scholarly attention on this topic, especially since Islamist movements, though largely absent from the initial protests, have come to play a prominent role in the aftermath of the uprisings with various degrees of success. These events have pushed them to shift from social movements to fully-fledged political parties, which consequences that remain to be interrogated (Al-Arian, 2014), but that have often been made to fit into the preestablished categories evoked above. 


\section{Tunisia: Explaining the Anomaly}

The studies of Tunisia and its transition since 2011 have largely been influenced by these various trends, particularly the compatibility question and the moderation-inclusion paradigm. Tunisia has attracted a lot of attention as the - currently - only case of completed democratic transition following the Arab Spring, though the question of consolidation remains (Brownlee et al., 2015). Though studies have focused on topics as varied as constitutionalism, the role of social media, youth, or women, in many accounts religion remained a key factor.

In many cases the language of compatibility dominated the studies: for instance, Brownlee et al. described in detail the debate around democracy and its implementation following Ben Ali's flight with the Islamists perceived as a potential danger for the fledgling regime (Brownlee et al., 2015). Going further, Cesari refused to categorize Tunisia as a democracy despite acknowledging that its transition, as opposed to other countries of the region, did go along as hoped, and invented the category of unsecular democracy to describe it because "the possible Tunisian democracy will retain some Islamic features" (Cesari, 2014, p. 238), a characteristic that seemed to fundamentally prevent it from being considered a full democracy. Hamid conceded that Tunisia stood as an exception, and took great care to distinguish between democracy and liberalism when exploring the attitudes of Islamist movements, but nonetheless asserted that Ennahda's commitments to democracy did not run very deep, and that their overall aim remained the Islamicization of society - apparent moderation, but fundamental incompatibility (Hamid, 2014). Even Cavatorta and Merone, when considering Ennahda's evolution, rely on the assumptions of the moderation model (Cavatorta and Merone, 2013).

The question of the impact of liberalization on the Islamist movements themselves has been hinted at but rarely fully theorized: Alvi described the balancing act between secularism and Islamism in Tunisia and seemed to hint at a form of liberalization in Ennahda itself without fully teasing out the theoretical implications of this evolution (Alvi, 2019), while Al-Arian saw internal shifts within the movements to adapt their ideology and organizational structures to the new political realities (Al-Arian, 2014). More decisively, Marzo shared this view and stated that internal transformations within Ennahda, once it had gained enough political capital, led it to adopt a more pro-democratic stance and play a key role in the democratization process (Marzo, 2018).

The Tunisian story has thus mainly been approached with a priori assumptions that attributed ulterior motives to its main actors. It has rarely been assessed on its own merit, without normative biases, and a full account of the democratization process and the role of religious forces in it is still missing; this gap can be filled using Villalón's framework.

\section{The Substance of Democracy}

Democracy is one of the most debated concepts of comparative politics and the literature has long been plagued by debates of definition, with for instance Collier and Levitsky famously proposing the idea of "democracy with adjectives" to account for the increasing variety of democratic regimes (Collier and Levitsky, 1997), while Coppedge et al. (2011) argued for disaggregation as a way to finetune measurement. Recent developments have made these questions particularly relevant as scholars now not only study what makes a regime democratic but also what can lead to the loss of this title, with increased emphasis on notions such as democratic backsliding (Waldner and Lust, 2018) or democratic decline (Kaufman and Haggard, 2019). Despite the variety of approaches, indexes, and other conceptualizations, most of these works share a core assumption: a country is democratic when it ticks a number of boxes and risks sliding back on the democratic scale when it no longer fits the description. Determining which criteria should be included on the list is at the heart of the literature on the topic, with some favoring minimalist definitions limited to the existence of elections while others opt for maximalist understandings including personal freedoms or minority rights, but the underlying assumption remains unchanged. It also echoes throughout the works discussed in the previous sections, as scholars assess the relationship between Islam and the aforementioned criteria list. 
Villalón moves away from this assumption as his core argument is that the compatibility question is essentially mis-framed; indeed, he stated that "rather than positing democracy as a discrete phenomenon and asking whether any given factor (such as Islam, or a particular interpretation of Islam) facilitates or blocks its instauration, [one should consider] the politics of defining the content of democracy and interpreting the prescriptions of religious traditions as interactive phenomena, which intersect with other phenomena to shape emerging political outcomes" (Villalón, 2010, p. 346). According to him, the key question is how democracy is pursued, negotiated and appropriated in a given society or context, and when interrogating the role of religious forces one should focus on the way their structures, institutions, symbols and ideas influence the framing, discussion and shaping of the democratic question, and how this process in turn affects the power of social groups, the debates, and the reform of the state that follow. This has implications for the definition of democracy itself: instead of a bounded, static model, Villalón considered it a "set of not always cohesive political ideas, a repertoire of institutions developed by experimentation and shaped by historical accidents in various specific settings, and a broad ideological agenda borrowed and pushed from one context to another in a globalized world" (Villalón, 2010, p. 376). In this sense, democracy is the initial repertoire, a canvas which is then appropriated and modified in each context according to relations of power. Islam in its multiple dimensions is nothing but one of the forces in these relations, contributing to shape the outcome but not predetermining it. The focus on the analysis is thus on the process of democratization and how some of its protagonists mobilize religion in this framework.

Understanding the democratization process this way means taking a long-term approach in which the transition from the previous regime marks only the beginning of liberalization - in the cases Villalón studied, the first democratic elections was the beginning of the debate on rule-writing. The focus needs to be on long-term transformations of the political sphere and the mobilization of social groups attempting to control the agenda and the outcome of the reform process, which thus leads to the confrontation between secular and religious groups and their respective visions of the political order. The former often come first: Villalón describes religious leaders as initially suspicious of liberalization but overcoming their reluctance when they realize their demographic advantage in a democratic setting.

The political sphere thus becomes a space for various constituencies to negotiate ways to adapt democracy to their respective visions of a good social and political order. This raises the question of what constitutes the core elements of democracy, universal and nonnegotiable, and what can be adapted to various cultural and social contexts; it also means that there needs to be space for this democratic bargaining without predetermined answers, and space for "some forms of nonliberal public argument within religious communities, in such democratic bargaining" (Villalón, 2010, p. 379). This political bargaining, this democracy in practice, produces two key dynamics: the rise of religion in public life, and the democratization of the religious sphere. The former is made possible because the bargaining process makes religious critique of the political order possible and leads to the politicization of new issues that did not necessarily fall within the public debate before but are core preoccupations of religious groups (such as the nature of the state, or family law), as these groups are newly empowered to pursue their agendas in the public sphere. The latter partly results from the former, as new voices come to challenge the existing authorities on religious grounds and compete for the legitimacy of religious endorsements, and the debate on religious truths and interpretations takes place on a wider range of topics ${ }^{2}$. The rise of religious influence in the public sphere, far from a threat to democratization, is thus a product of its dynamics and reflects a sizeable part of the public opinion, bringing the political closer to social and cultural realities. It must be noted, however, that what characterizes this process is that it leads to compromise: acrimonious debates pitting secularists against Islamists do take place, but "the stark oppositions are being subtly eroded, and these contentious and difficult political issues are being incrementally negotiated"; in this context Villalón invites us to consider "the possibility that the functioning of democracy itself might lead not to irreconcilable clashes but to negotiation and gradual accommodation" (Villalón, 2010, p. 389).

\footnotetext{
2 This echoes the idea of the multivocality of religion, which makes the compatibility question moot as well.
} 
Villalón built his analysis on the study of three cases, Mali, Niger, and Senegal, which shared common features that are not necessarily found in Tunisia such as ethnic and linguistic pluralism (Villalón, 2010). However, these may not prove to be their most relevant characteristics. Indeed, as will be shown below, much of the events that unfolded in Tunisia after the fall of Ben Ali followed the same trajectory and dynamics as those happening in the 1990s in sub-Saharan Africa. In these three cases, religious movements played a minor role in the fall of authoritarianism but came to occupy a central place in the following debates, as the strict boundaries imposed on them by the previous regime fell and a plurality of voices rose - even in Senegal, where the Sufi orders traditionally held sizeable power and influence (Villalón, 2013). Questions that had appeared to be settled on the secular side, such as the nature of the state or the family code, became the topic of debate - to the dismay of many proponents of secularism under the French model - even if ultimately the status quo prevailed.

Far from being a threat to democracy, this process constitutes its very essence, which is what has been missed by many commentators of the Tunisian events. The question is not whether democracy is compatible with Islam but how it is practiced in Muslim contexts and societies; religion is one of the many social factors that shape the political outcome, but it does not determine nor preclude it. Using this framework solves the issues of many of the other approaches evoked above, including the normative biases of the moderation-inclusion framework; the question is not where social forces are situated on a democratic spectrum but whether they are taking part in the bargaining process, and accepting and abiding by its compromises. As will be shown below, the case of Tunisia falls within the processes and dynamics described by Villalón, and using his metrics allows for a less biased assessment of the Tunisian transition and the role of Islamist movements in it.

\section{Tunisian Democracy: Triumph of the Compromise}

\section{Setting the Scene}

The protests that led to the departure of Ben Ali from Tunisia in January 2011 marked the onset of what would come to be known as the Arab Spring, but it also marked the beginning of a very specific and long-winding transition process. Members of the regime attempted to remain in power in the wake of the flight of the dictator, but protesters managed to put enough pressure on the government to ensure that civil society, and in particular the unions and the professional associations that had led the demonstrations, had reasonable control over the transition. Here Tunisia already followed the path evoked by Villalón: the Islamist movements were not among the initiators of the uprisings, and political Islam was not at the forefront of what were essentially socioeconomic demands and a yearning for change (Kamrava 2014); the movements joined the game later on, though they did so forcefully. Their involvement started from the beginning of the transition process, in the leadup to the elections that were held on the $23^{\text {rd }}$ of October 2011 to choose the members of the constituent assembly that would be tasked with re-imagining the political structure of the country and act as an interim legislative chamber until the adoption of the new constitution (Brownlee et al., 2015a).

Eighty-one political parties were created or re-authorized during the run-up to the elections and it would be beyond the scope of this paper to name them all, but a few of them deserve attention: first and foremost was Ennahda, an Islamist movement turned political party founded in 1981 that had been violently repressed under the dictatorship and whose leadership, including its famous leader Rachid Ghannouchi, had been in exile until Ben Ali's fall (Brody-Barre, 2012); the Congress for the Republic, led by Moncef Marzouki, a renowned human rights lawyer and opposition figure; and the Democratic Forum for Labor and Liberties, led by Mustapha Ben Jaafar, known as Ettakatol. These would remain prominent until the adoption of the Constitution in 2014 (Brownlee et al., 2015a), before being joined by Beji Caid Essebsi's Nida'a Tounes alliance.

\section{1: The Rise of the Religious}

As Villalón's model predicts, the transition period saw a notable rise of religious discourse in the public sphere in Tunisia. Ben Ali's regime had made a point of suppressing religious displays in 
the public space, even criminalizing religious conduct in some cases, but it appeared quickly that this enforced secularism had only driven people's beliefs underground, not erased them (Nachi, 2016). For many the newfound liberties included that of freely exercising their religion: "In the months after the revolution, [...] the headscarf, along with the more conservative abaya, could also be seen in growing numbers. Women protested for the right to wear the niqab-showing only their eyes and nothing else-at universities. Religious charities and organizations proliferated" (Hamid, 2014, pp. 195-6). In this new political space religious affiliations became a matter of public debate and political actors took up the defense of Islamic values newly assimilated to the Tunisian national identity as a way to break from the era of authoritarianism (Nachi, 2016).

The party that came to embody this aspiration for political Islam was Ennahda. Its leaders came back from exile with the legitimacy of years spent in the opposition, and the advantage of an existing network and mobilization capabilities (Hamid 2014), but their popularity among Tunisians cannot only be explained by their organization capacities. They came back to a country that was ready for them and their mix of religion and politics, and they managed to successfully keep Islam as a public question and put it at the center of the political agenda, thereby bolstering their own position (Nachi, 2016). The strategy was successful: Ennahda won $41 \%$ of the votes in the October election, which translated to 89 of the 217 seats of the transitional assembly. This popularity endured: "a Pew Research Center Study, after the election in mid-2012, continued to show that Tunisians had a favourable view of al-Nahda, with 65 per cent approval" (Alianak, 2014, pp. 47-8).

It must be noted that this popularity did not drive Ennahda to intransigence, neither before nor after the polls, even though it was faced with sizeable opposition from secular and leftist parties. There had been some disagreements around the date of the election, which the interim government sought to postpone (the initial date was in July), a move initially opposed by Ennahda. This position was understandable as it had an edge in the poll that newer parties were struggling to match, though it finally agreed to compromise on the October date. Another issue was the length of the constitutional process: before the election a coalition of smaller parties argued that it should be limited to six months, a proposition rejected by Ennahda and Marzouki: "according to many observers, some non-Islamists feared that Ennahdha was poised to capture a majority in the assembly, and therefore these nonIslamists wanted to limit both the assembly's term and its mandate, lest it prove the gateway to Islamist dominion" (Brownlee et al., 2015a, pp. 136). This issue proved thornier, but the transition council hosted a dialogue between the 11 most prominent parties that led to the signing of a common declaration stating that the assembly's term should not exceed one year but that it would elect a new president, striking a middle ground compromise. After the elections, Ennahda also opted for the middle ground by forming a coalition government with the parties that came in second and third, the Congress for the Republic and Ettakatol, and divided the posts of Prime Minister, President, and Parliamentary Speaker among them (Al-Arian, 2014).

If we follow Villalón's prescriptions, these developments were the signs of a healthy democratization process; against the misgivings of some like Brownlee, Masoud and Reynolds who saw the rise of Islamists as a worrying sign, and the alliance of secularists against them as reassuring (Brownlee et al., 2015a), their rise was actually the proof that what was happening in 2011 was the unfolding of democracy à la Tunisienne after years of repression, a new model actively negotiated between religious and secular forces reflecting the will of the population. The Constitutional process, as detailed below, provides perhaps the best illustration of this dynamic.

\section{Forging the Constitution}

As anticipated by Villalón, the constitutional process led to the politicization of a range of new topics that had previously been settled on the secular side. The first of these topics concerned the nature of the state and its identity: in the first draft of the constitution published in April 2013, the preamble insisted on Tunisia's "cultural and civilizational affiliation to the Arab Islamic nation" (Brownlee et al., 2015a, pp. 144), which was seen as too much of a concession by the secularists. Similarly, the first article of the previous constitution stated that "Tunisia is a free, independent and sovereign State. Its religion is Islam, its language is Arabic and its type of government is the Republic" (Cesari, 2014, p. 243), a formulation that was seen as ambiguous - for some indicating that Islam 
was the state's religion, for others simply reflecting the faith of a majority of Tunisians. Debates started when secularists tried to remove it, a position which Ennahda opposed as likely to undermine the sense of identity of Tunisians (Dalmasso and Cavatorta, 2013). In the meantime some supporters of Ennahda and other Islamist movements were arguing for the inclusion of sharia in the constitution as the basis of the law, a position which provoked debates within the party until Ghannouchi announced that it would not be supported officially - reflecting his will to keep the balance in the coalition, and cultivate the image of Ennahda as a moderate party (Marzouki, $2017^{3}$ ). Ultimately Article 1 was kept intact, as well as a former clause stipulating that the President should be Muslim, but the gender condition for the Presidency was removed, again striking a compromise between secular and religious priorities (Cesari, 2014).

A few other topics sparked similar controversies, including paragraphs concerning apostasy and women's rights, which were also settled by compromise and through the intervention of activists and protests (Alvi, 2019; Bellin, 2013; Marzouki, 2017). The resulting document was a reflection of this intricate bargaining process, sometimes to a fault: attempting to combine very different positions produced some awkwardly worded passages and unresolved ambiguities (Esposito et al. 2016). Despite this and some other issues, the final version of the Constitution adopted on the $27^{\text {th }}$ of January 2014 was much more liberal than those afraid of Ennahda's majority feared: it defined Tunisia as a civil state, protected women's rights, gender equality, and freedom of belief and conscience, and emphasized Tunisia's Arab and Muslim identity while acknowledging its pre-Islamic heritage (Marzouki, 2017). This was the fruit of a true democratic bargain, the outcome of deliberate choices and strategies: "the resolution of the numerous conflicts about the place of religion in the constitution is not an outcome of the victory of an ideology over another (secularist vs. Islamist). Rather it is an effect of a foundational dimension of the Tunisian constitutional process, the commitment to compromise" (Marzouki, 2017, pp. 343-4).

\section{Following Through and Finding the Light}

The constitutional process did not proceed without issues or tensions, inside and outside of the chamber. Ennahda's popularity attracted the ire of many, including secularists afraid of the Islamization of Tunisia (Marzouki 2017), and it was accused of cozying up to extremists and Salafist movements; when Chokri Belaid, an opposition activist, was assassinated in February 2013 presumably by Salafists - Prime Minister Jebali was forced to resign and replaced by Ali Laarayedh, also of Ennahda (Dalacoura, 2016). The killing of another opposition figure later in the year, Mohamed Brahimi, created another political crisis which led the speaker of the assembly Mustapha Ben Jaafar to suspend the proceedings until all parties had found an agreement on the way to proceed, helped in the negotiations by a coalition of civil society organizations ${ }^{4}$. Through their mediation the parties agreed to a roadmap that included the signing of the constitution, the appointment of an electoral commission, and the holding of new parliamentary and presidential elections in October 2014. Ennahda agreed to the roadmap except the demand that they would resign in favor of a technocratic government, demanding instead to stay in power until the constitution was approved - which they did (Stepan, 2018b).

Ennahda was sure enough of its victory in the parliamentary election that it chose not to run a candidate in the presidential election, so as to avoid being seen as having too much power. Under the 2014 Constitution, Tunisia is a hybrid regime in which executive power is split between the Head of Government, the head of the party holding a majority in Parliament, and the President; despite this split, the President retains the ability to propose draft laws and is responsible for most areas of defense and national security, which would indeed give a disproportionate influence to a party holding

\footnotetext{
${ }^{3}$ No tie to Moncef Marzouki.

4 This coalition known as the Tunisian National Dialogue Quartet and composed of the Tunisian General Labor Union (Union Générale Tunisienne du Travail), the Tunisian Confederation of Industry, Trade and Handicrafts (Union Tunisienne de l'Industrie, du Commerce et de l'Artisanat), the Tunisian Human Rights League (La Ligue Tunisienne pour la Défense des Droits de l'Homme), and the Tunisian Order of Lawyers (Ordre National des Avocats de Tunisie) went on to win the Nobel Peace Prize in 2015 (https://www.nobelprize.org/prizes/peace/2015/press-release/, last accessed December 19, 2019)
} 
both positions at the same time ${ }^{5}$. Ennahda's calculations proved too optimistic however, and a plurality of the votes was instead won by Nida'a Tounes, a coalition born out of the alliance of a collection of smaller parties and led by long-time politician Beji Caid Essebsi who went on to win the presidential election as well (Brownlee et al., 2015a ). Though initially vocally opposed to Ennahda, Nida'a Tounes chose to build a coalition that included them as well as three other parties, though it only allocated them one Ministry and three other cabinet positions (Marks, 2018). This compromise appeared to have been founded on pragmatic calculations: Nida'a Tounes chose partners that shared its economic views - the most pressing issue for Tunisians - rather than ideological orientations (Stepan, 2018b ). This illustrates a key point of this dynamic: as highlighted by Marzo, Ennahda has shown clear signs of transformation that have narrowed the political distance between secularists and Islamists: "Political debate is now gradually showing features of a modern confrontation, mainly focused on how to rule the country. [...] The economy, administrative reforms and justice are the core issues discussed in Parliament. Although strong opposing views often characterize the debate, the overall situation is less polarized, with groups of MPs from different blocks co-operating over specific issues" (Marzo, 2018, p. 15). As predicted by Villalón, the democratic bargaining process has led to more compromise, the "stark oppositions are being subtly eroded", and contentious issues are being negotiated. This is a clear sign, as assessed by Brownlee (2015), that democracy has taken root.

\section{Liberalizing the Religious}

Those key instances illustrate rather well the rise of religious influence in politics following the beginning of the liberalization process in Tunisia. The second dynamic was also at play, with the end of authoritarianism leading to the pluralization of religious voices.

Nachi described the multiplications of "new 'religious entrepreneurs' (imams, muftis, preachers, etc.) and new 'religious products' (books, websites)" made possible by the "ongoing process of democratization [which] unleashed repressed forces and enabled the diversification of the religious 'supply' in terms of Islamic discourses, practices and manifestations" (Nachi, 2016, pp. 5001). Despite this frenzy, the main organized movements that benefitted from this opening were the Salafist parties and currents that had long been repressed. Cavatorta also singled out the fall of the Ben Ali regime as the principal cause of their emergence as the accompanying freedom of expression allowed them to mobilize and recruit more easily, all the while not opposing democracy itself but only its more liberal components (Marks, 2018; Cavatorta, 2015). These movements had widely different interpretations of the role of Islam in politics, especially compared to Ennahda: "the moderate politicalreligious interpretation of Islam that [...] was then diffused among the followers of an-Nahda for many years, was very distant from the ultra-conservative doctrine spread by supporters of Hizb ut-Tahrir" and one of its pillars "was that the biggest enemy of Islam is not relaxation of its precepts but rather tyranny and the traditionalist interpretation of religion that is a common aspect of radical Salafism" (Martinez Fuentes, 2017, p. 181). These parties competed for the votes of the ultra-conservatives, though not all of them were willing to play by the rules of the political game.

Their rise challenged Ennahda's position as the main authority on political Islam (Hamid, 2014), which forced it to sometimes perilous compromises as an attempt to both demonstrate its Islamist credentials to satisfy its base and try not to alienate its secular partners (Drumberg, 2014). This balancing act proved sometimes too difficult to maintain and led to the loss of some voters to more extreme movements (Hamid, 2014), which has been used to explain the slow response of Ennahda to the 2013 events as well as earlier polemics by fear of alienating its conservative fringe and losing further support (McCarthy, 2015) ${ }^{6}$.

This phenomenon also increased pluralization within Ennahda. The question of the inclusion of sharia in the constitution in particular proved particularly divisive and highlighted the presence of a pragmatic current opposed to a more ideologically pure tendency, though the leadership ultimately adjusted its strategy to the broader political landscape and the demands of the secularists (Cesari,

\footnotetext{
${ }^{5}$ https://www.constituteproject.org/constitution/Tunisia 2014.pdf, last accessed July 14, 2020)

${ }^{6}$ Ennahda did declare Ansar al-Sharia a terrorist group in 2012, marking its distance with the more extreme Islamist movements
} 
2014; Martinez Fuentes, 2017). Ennahda had long operated as an internal democracy, but this issue in particular emboldened the conservative elements within, led by Habib Ellouze, who argued that the party was losing touch with popular sentiment (Hamid 2014). Ennahda held together despite these disagreements, but they had an impact on its internal structure which became increasingly fractionalized, a trend that facilitated its internal democratization and pluralization to the point that it officially renounced Islamism - arguing that protecting religion was no longer needed in the new Tunisia (Marzo, 2018; Sadiki, 2018).

Participation in the democratization process also influenced Ennahda's position on the international scene. Cavatorta and Merone point out that despite residual anti-Americanism tied to the reaction to the 1991 and 2003 invasions of Iraq, Ennahda came to adopt a pragmatic approach on foreign policy and agreed to crackdown on Salafi activism following US demands after the attack on the US embassy in Tunis in 2012 (Cavatorta and Merone, 2013). Marzo also mentions that Ennahda accepted and even sought support and technical assistance from international development partners based in the West during the democratization process, illustrating its evolving stance (Marzo 2020).

It thus seems that Tunisia followed the framework outlined by Villalón: the first elections after the fall of the dictatorship only marked the beginning of a long process of political rule-making, in which religious movements played a key role reflecting their popularity among the population, but the religious context in itself did not determine the political outcomes which were the product of a thorough negotiation. This process led to the moderation of the parties involved as well as the democratization of the religious sphere, ultimately producing a democratic bargain reflecting the social and cultural context in which it was taking place. Following Villalón's steps thus allows us to move beyond questions of compatibility or normative biases and reassess the Tunisian transition process on its own merit. However, some qualifications are in order.

\section{Tunisian Exceptionalism?}

\section{The Peculiar Story of Ennahda}

If Tunisia stands alone as the success story of the Arab Spring, Ennahda is often viewed as an unusual and potentially non-representative examples of Islamist movements and its moderation and democratization tendencies have been heavily scrutinized. For many, its democratic participation can be attributed to the dynamics identified by Villalón: they argue that its choices have been directed by its intrinsic edge in the democratic game brought by the popularity of political Islam, which led it to embrace democracy and kept it invested in it (Noueihed and Warren, 2012; Esposito et al., 2018), that they are the result of progressive socialization and civic habituation (Dalmasso and Cavatorta, 2013; Sadiki, 2018), or that both phenomena are playing out at the same time (McCarthy, 2015).

Though these dynamics were undeniably at play, other factors must be taken into account in this case. First of all, Ennahda's political career began in a particularly harsh environment of violence and repression - much more than Sufi movements in Senegal studied by Villalón for instance, which were never repressed even under the one-party regime. This has infused Ennahda, its leadership, and its members with enough of a fear of a return to autocracy to push it to compromise even on core issues, as temporary retreat was perceived as better than stoking the fears of the secularists to the point of justifying another repressive episode (Cavatorta and Merone, 2013; Netterstrøm, 2015). This fear was reinforced by the example of the Muslim Brotherhood in Egypt, whose refusal to compromise and share power after its electoral victory was seen as one of the reasons for the military coup and brutal crackdown that put an end to the Morsi presidency (Masri, 2018). As shown by the events of 2013 and the association of Ennahda with the Salafists, this fear was not without reason: distrust of Ennahda ran deep among secularists who "continued to suspect strongly that [it] constituted an Islamofascist wolf in sheep's clothing" (Marks, 2018, p. 99), bent on imposing a theocracy despite their repeated denials (Hamid, 2014). These contextual elements have been used to explain Ghannouchi's unprecedented prudence, which led him to accept unpromising compromises, refuse to run a candidate for the 2014 presidential election, and advocate for a proportional representation system in 2011 even though it would mean that Ennahda would lose a sizeable share of the votes, 
just to avoid being seen as winning too much too quickly and becoming a threat (Marks, 2018; Stepan, 2018b).

Another argument that has been raised to explain Ennahda's behavior is to be found in history as well: Ennahda has been part of the opposition to Ben Ali since 2003 and the creation of the Call of Tunis manifesto (Bellin, 2013), alongside secular and liberal movements led by Marzouki and Ben Jaafar among others (Marks, 2018). The platform that this opposition group put forward under the name Collectif du 18 Octobre was deeply inspired by non-religious groups and reflected their priorities such as the protection of human rights, personal freedoms, and gender equality (Marls, 2018; Stepan, 2018b). This has been taken as showing a history of pragmatism and concern for compromise beyond ideology that predates any form of democratic participation and was key in the cohabitation of the main parties throughout the transition process (Alianak, 2014; Marzouki, 2017). This tradition of liberalism on the part of Ennahda has been duly contested by those who see it as simply biding its time until it can fulfil its ulterior motives but these doubts have so far failed to materialize (Hamid, 2014, pp. 197-8; Marks 2018).

\section{Chicken, Egg, and Causality}

Another issue to consider is that Villalón's model focuses quite strictly on the structural effects of democratic bargaining, but some have argued that the Tunisian events have much to do with a different set of factors. The role of the army, which featured prominently in the Egyptian case, is an excellent example: for Brownlee, Masoud and Reynolds for instance, the key difference between Egypt and Tunisia was that in the latter economic and social structures shaped the party leaders' electoral fortunes in ways that encouraged them to compromise, which was not the case for the former; these conditions thus determined the choices and decisions that created the presence or absence of opportunity for the army to intervene (Brownlee et al., 2015b). Drumberg proposed another explanation for the difference: because Tunisia's military "did not have the experience, tools, or will to emulate the quasi-arbitrating role of Egypt's Supreme Council of the Armed Forces, Tunisia's civil society and political leaders eventually had to face each other and negotiate a common vision of political change, rather than look to the remnants of the ancient regime for protection" (Drumberg, 2014, p. 50).

For Esposito, Sonn and Voll, a mix of causes that only partly fit within Villalón's model needed to be considered: they stated that Tunisia's success should be attributed to "its stronger civil society organizations, the military's professionalism, and the responsiveness and significant concessions made by Ghannouchi and Ennahda" (Esposito et al., 2016, p. 200). The design of the electoral system, which made it more difficult for one party to obtain a majority unlike in Egypt, has also been highlighted as a potential cause, though this can be traced back to Ghannouchi's leadership (Ghanem, 2016). For many, this combination was too fragile to be replicated elsewhere - Tunisia was an anomaly in the Middle East, the product of exceptional circumstances that included the absence of external meddling, be it by armed forces or foreign powers, and a particularly clairvoyant elite (Bellin, 2013; Esposito et al., 2018). In any case, Ennahda's moderation has been attributed to a range of factors that questions the strict causal line drawn by Villalón: this does not invalidate the model, but emphasizes the fact that when transposed to a new context, it needs to accommodate a wider range of factors shaping actors' behavior.

\section{Beyond Religion}

If this makes clear that religious forces are not a threat to democracy per se, there are indirect effects to the bargaining process that Villalón failed to account for but that nonetheless pose serious risks to democratic consolidation. The rise of religion in the public sphere and the subsequent politicization of new topics has made these questions, and the role of religion more generally, the central preoccupation of politicians, often to the detriment of other issues that were central to voters (Alianak, 2014; Brody-Barre, 2012). The economy and unemployment rate, which were the key issues that led to the uprisings, have been sidelined for a time and the situation has worsened since 2011 in many places, which has contributed to a growing disinterest from politics and a distrust of the major parties (Alianak, 2014; Masri, 2018). This has been compounded by the fact that the political evolution 
of Ennahda has driven it closer to the middle class and led to the marginalization of many of those who started the protests, who see their grievances remain unaddressed (Koehler and Warkotsch, 2014; Marzo, 2018). The failure of the government to guarantee security, as shown by the terrorist attacks at the Bardo museum and Port-el-Kantaoui in 2015, have reinforced these fears as well as endangered tourism, one of the key sectors of the Tunisian economy (Ghanem, 2016; Stepan, 2018b).

Villalón himself admitted that his cases had their weaknesses, and his assessment that "there are, to be sure, limitations to these ongoing experiments with democratization, yet their substance is nonetheless undeniable" (Villalón, 2010, p. 375) seems particularly apt in the case of Tunisia. Even if the rejection of existing parties in the 2019 presidential election - the two candidates that reached the second round were proudly anti-establishment and the new President, Kais Saied, had avowedly never voted before ${ }^{7}$ - is not the same as the rejection of democracy altogether, the fact that trust in Parliament in 2019 has fallen to 14 percent, and that trust in political parties stands at just 9 percent according to the Arab Barometer ${ }^{8}$, is not promising. Analysts should stop worrying about Islamists, but this does not necessarily mean that the battle for democratic consolidation is won.

\section{Conclusion}

Villalón's framework sheds a new and interesting light on the Tunisian democratic process, and on the prospects for democracy in the Middle East in general. Using it would have allowed a rather thorough prediction of the 2011-2014 events and challenged many of the accounts that saw the rise of Ennahda as a threat to democracy. It shows that Islamist movements should be studied without a priori assumptions and can play a critical role in the construction of democracy, if only because of their undeniable popularity, if they participate in the bargaining process that actually is the very substance of democratization.

It also provides an alternative understanding of democracy free of the normative assumptions that precluded many analysts from seeing the events unfolding in Tunisia as bearing the mark of true democratization. Moving away from considering democracy as a set of indicators or boxes ticked, adopting a "practice turn" bringing the focus back on the actors and practitioners of democracy, and conceptualizing it as a practice to be evaluated in the long-term is a fruitful way to sidestep many of the issues of the contemporary literature on the topic and include examples such as Tunisia that are not usually considered by scholars but add much to our understanding of what democracy can look like in different settings.

There are, however, limits to this approach. History has shaped Ennahda in particular ways, and factors that Villalón sees as exogenous to the model, such as the role of the armed forces, need to be accounted for to explain the Tunisian exception. It appears that what did not happen mattered as well as what did, and that Villalón's prediction were realized most likely because Tunisia was sheltered from many of the forces that derailed democratization in other places. However, this does not mean that his approach should be discounted. More research might be needed to complement the framework and make it more generalizable to the Middle East and other regions, but it opens the door to better understandings of democratic bargaining in Arab and Muslim contexts, decisively debunks the notion of the Arab democratic gap, and introduces a new perspective on the nature of democracy itself.

\footnotetext{
${ }^{7}$ Financial Times "Democracy Hangs in the Balance in Tunisia", Safwan Masri, 26 September 2019 (https://www.ft.com/content/7db6ae96-dfac-11e9-b8e0-026e07cbe5b4 last accessed Dec 17, 2019)

${ }^{8}$ New York Times "The Future of Democracy in Tunisia", Rory McCarthy, 24 September 2019

(https://www.nytimes.com/2019/09/24/opinion/tunisia-democracy.html last accessed Dec 17, 2019)
} 


\section{References}

Books, Chapters and Articles

Al-Arian, A. (2014). "Islamist Movements and the Arab Spring." In Beyond the Arab Spring: The Evolving Ruling Bargain in the Middle East, (M. Kamrava, Ed.). Oxford: Oxford University Press. DOI: 10.1093/acprof:oso/9780199384419.001.0001

Alianak, S. L. (2014). The Transition Towards Revolution and Reform: The Arab Spring Realised? Edinburgh: Edinburgh University Press.

Alvi, H. (2019). The Political Economy and Islam of the Middle East: The Case of Tunisia. Cham: Springer Nature Switzerland. DOI: 10.1007/978-3-030-17050-9

Bayat, A. (2007). "Islam and Democracy: What is the Real Question?" ISIM Paper 8, 6-25. Leiden: Amsterdam University Press.

Bellin, E. (2013). "Drivers of Democracy: Lessons from Tunisia." Middle East Brief 75, Crown Center for Middle East Studies, Brandeis University: pp 1-11.

Brody-Barre, A. G. "The Impact of Political Parties and Coalition Building on Tunisia's Democratic Future." The Journal of North African Studies 18(2), 211-230. DOI: 10.1080/13629387.2012.742365

Brownlee, J. (2015). "Introduction: The Third Arab Spring." In The Arab Spring: Pathways of Repression and Reform, (J. Brownlee, T. Masoud, and A. Reynolds, Eds.). Oxford: Oxford University Press. DOI: 10.1093/acprof:oso/9780199660063.001.0001

Brownlee, J., T. Masoud and A. Reynolds. 2015a. "Post-breakdown Trajectories" The Arab Spring: Pathways of Repression and Reform, (J. Brownlee, T. Masoud, and A. Reynolds, Eds.). Oxford: Oxford University Press. DOI: 10.1093/acprof:oso/9780199660063.001.0001

- 2015b. "Why Breakdowns Did Not Always Produce Transitions" In The Arab Spring: Pathways of Repression and Reform, (J. Brownlee, T. Masoud, and A. Reynolds, Eds.). Oxford: Oxford University Press. DOI: 10.1093/acprof:oso/9780199660063.001.0001

Brynen, R., P. W. Moore, B. F. Salloukh, and M.-J. Zahar (2012). Beyond the Arab Spring: Authoritarianism and Democratization in the Arab World. Boulder: Lynne Rienner Publishers.

Cavatorta, F. (2015). "Salafism, Liberalism, and Democratic Learning in Tunisia." The Journal of North African Studies 20(5), 770-783. DOI: 10.1080/13629387.2015.1081464

Cavartora, F. and F. Merone (2013). "Moderation through exclusion? The journey of the Tunisian Ennahda from fundamentalist to conservative party." Democratization 20(5), 857-875. DOI: $10.1080 / 13510347.2013 .801255$

Cesari, J. (2014). The Awakening of Muslim Democracy: Religion, Modernity, and the State. Cambridge: Cambridge University Press.

Collier, D. and S. Levitsky (2010). "Democracy with Adjectives: Conceptual Innovation in Comparative Research." World Politics 49(April), 430-451.

Coppedge, M., J. Gerring, D. Altman, and M. Bernhard (2011). "Conceptualizing and Measuring Democracy: A New Approach." Perspectives on Politics 9(02), 247-267. DOI: 10.101 7/S1537592711000880

Dalacoura, K. (2016). "Islamism and Neoliberalism in the Aftermath of the 2011 Arab Uprisings: The Freedom and Justice Party in Egypt and Nahda in Tunisia." In Neoliberal Governmentality and the Future of the State in the Middle East and North Africa (E. Akçali, Ed.). London: Palgrave Macmillan.

Dalmasso, E. and F. Cavatorta (2013). "Democracy, Civil Liberties and the Role of Religion after the Arab Awakening: Constitutional Reforms in Tunisia and Morocco." Mediterranean Politics 18(2), 225-241. DOI: 10.1080/13629395.2013.799341

Dorraj, M. (1999). "Islam, Governance and Democracy." In Middle East and North Africa: Governance, Democratization and Human Rights, (P. J. Magnarella, Ed.). London: Routledge.

Drumberg, D. (2014). "Theories of Transition." In The Arab Uprisings Explained: New Contentious Politics in the Middle East (M. Lynch, Ed.). New York: Columbia University Press.

Esposito, J. L., T. Sonn and J. O. Voll (2016). Islam and Democracy after the Arab Spring. Oxford: Oxford University Press. DOI: 10.1093/acprof:oso/9780195147988.001.0001 
Esposito, J. L., L. Zubaidah Rahim and N. Ghobadzadeh (2018). "Introduction: Theological Contestations and Political Coalition-Building." In The Politics of Islamism: Diverging Visions and Trajectories, (J. L. Esposito, L. Zubaidah Rahim and N. Ghobadzadeh, Eds.). New York: Palgrave Macmillan. DOI: 10.1007/978-3-319-62256-9_1

Ghanem, H. (2016). The Arab Spring Five Years Later. Washington, DC: Brookings Institution Press. Ghannouchi, R. (2018). "Ennahda's Democratic Commitments and Capabilities: Major Evolutionary Moments and Choices." In Democratic Transition in the Muslim World: A Global Perspective, (A. Stepan, Ed.). New York: Columbia University Press.

Hamad, M. and K. al-Anani (2014). "Elections and Beyond: Democratization, Democratic Consolidation, or What?" In Elections and Democratization in the Middle East: The Tenacious Search for Freedom, Justice, and Dignity (M. Hamad and K. al-Anani, Eds.). New York: Palgrave Macmillan.

Hamid, S. (2014). Temptations of Power: Islamists and Illiberal Democracy in a New Middle East. Oxford: Oxford University Press.

Hashemi, N. (2013). "Islam and Democracy." In The Oxford Handbook of Islam and Politics, (J. L. Esposito and E. El-Din Shahin, Eds.). Oxford: Oxford University Press. (online access: https://www-oxfordhandbooks-com.proxy3.library.mcgill.ca/view/10.1093/oxfordhb/ 9780195395891.001.0001/oxfordhb-9780195395891-e-037, last accessed Dec 16 2019)

Hefner, R. W. (2012). "Rethinking Islam and Democracy." In Rethinking Religion and World Affairs, (T. S. Shah, A. Stepan and M. Duffy Toft, Eds.). Oxford: Oxford University Press. DOI: 10.1093/acprof:oso/9780199827978.001.0001

Kadivar, M. (2018). "Islam and Democracy: Perspectives from Reformist and Traditional Islam." In The Politics of Islamism: Diverging Visions and Trajectories (J. L. Esposito, L. Zubaidah Rahim and N. Ghobadzadeh, Eds.). New York: Palgrave Macmillan.

Kamrava, M. (2014). Beyond the Arab Spring: The Evolving Ruling Bargain in the Middle East. Oxford: Oxford University Press. DOI: 10.1093/acprof:oso/9780199384419.001.0001

Kaufman, R. R. and S. Haggard (2019). "Democratic Decline in the United States: What Can We Learn from Middle-Income Backsliding?" Perspectives on Politics 17(2), 417-432. DOI: https://doi.org/10.1017/S1537592718003377

Koehler, K. and J. Warkotsch. (2014). "Tunisia Between Democratization and Institutionalizing Uncertainty." In Elections and Democratization in the Middle East: The Tenacious Search for Freedom, Justice, and Dignity, (M. Hamad and K. al-Anani, Eds.). New York: Palgrave Macmillan.

Maboudi, T. (2019). "Reconstituting Tunisia: Participation, Deliberation, and the Content of Constitution." Political Research Quarterly, 1-16. https://doi.org/10.1177/1065912919854802

Marks, M. (2018). "Purists and Pluralists: Cross-Ideological Coalition Building in Tunisia's Democratic Transition." In Democratic Transition in the Muslim World: A Global Perspective, (A. Stepan, Ed.). New York: Columbia University Press.

Martínez Fuentes, G. (2017). "Political Islam in Tunisia: A Comparative Approach." In Political Islam in a Time of Revolt, (F. Izquierdo Brichs, J. Etherington and L. Feliu, Eds.). New York: Palgrave Macmillan. DOI 10.1007/978-3-319-52833-5_8

Marzo, P. (2018). "Critical junctures, path dependence and Al-Nahda's contribution to the Tunisian transition to democracy." The Journal of North African Studies, 1-21. DOI: 10.1080/ 13629387.2018.1480943

(2020). "International democracy promoters and transitional elites: favourable conditions for successful partnership. Evidence from Tunisia's democratization." Cambridge Review of International Affairs 33(3), 307-329. DOI: 10.1080/09557571.2019.1636765

Marzouki, N. (2017). "Dancing by the Cliff: Constitution Writing in Post-Revolutionary Tunisia, 20112014." In Constitution Writing, Religion and Democracy, (A. Ü. Bâli and H. Lerner, Eds.). Cambridge: Cambridge University Press. DOI: 10.1017/9781107707443.014

Masri, S. M. (2018). Tunisia: An Arab Anomaly. New York: Columbia University Press.

McCarthy, R. (2015). "Protecting the Sacred: Tunisia's Islamist Movement Ennahdha and the Challenge of Free Speech." British Journal of Middle Eastern Studies 42(24), 447-464. DOI: 10.1080/ 13530194.2015.1005055

Merone, F. (2015). "Enduring Class Struggle in Tunisia: The Fight for Identity beyond Political Islam." British Journal of Middle Eastern Studies_45(1), 74-87. DOI:10.1080/13530194.2015.973188 
Nachi, M. (2016). “The Construction of Religion as a 'Public Problem': The Emergence of Islam in the Public Space During Tunisia's Transition to Democracy (2011-2014)." Social Science Information 55(4), 495-510. DOI: 10.1177/0539018416658152

Netterstrøm, K. L. (2015). "After the Arab Spring: The Islamists' Compromise in Tunisia." Journal of Democracy 26(4) (October), 110-124. DOI: 10.1353/jod.2015.0055

Noueihed, L. and A. Warren (2012). The Battle for the Arab Spring: Revolution, Counter-Revolution and the Making of a New Era. New Haven: Yale University Press.

Otayek, R. and B. F. Soares. (2007). "Introduction: Islam and Muslim Politics in Africa." In Islam and Muslim Politics in Africa, (R. Otayek and B. F. Soares, Eds.). New York: Palgrave Macmillan. DOI 10.1057/9780230607101

Rahman, F. Z. (2013). "Determinants of Democracy in the Muslim World." In Polity 45(4) (October), 554-579. DOI: $10.1057 /$ pol.2013.18

Sadiki, L. (2018). "Tunisia's Ennahda: Islamists Turning the Learning Curve of Democracy and Civic Habituation." In The Politics of Islamism: Diverging Visions and Trajectories, (J. L. Esposito, L. Zubaidah Rahim and N. Ghobadzadeh, Eds.). New York: Palgrave Macmillan.

Sadowski, Y. (1997). "The New Orientalism and the Democracy Debate." In Political Islam: Essays from Middle East Report, (J. Stork, Ed.). Berkeley: University of California Press.

Stepan, A. (2012). "Tunisia's Transition and the Twin Tolerations." In Rethinking Religion and World Affairs, (T. S. Shah, A. Stepan, and M. Duffy Toft, Eds.). Oxford: Oxford University Press.

- 2018a. "Introduction." In Democratic Transition in the Muslim World: A Global Perspective, (A. Stepan, Ed.). New York: Columbia University Press.

- 2018b. "Mutual Accommodation: Islamic and Secular Parties and Tunisia's Democratic Transition." In Democratic Transition in the Muslim World: A Global Perspective, (A. Stepan, Ed.). New York: Columbia University Press.

Villalón, L. (2010). "From Argument to Negotiation: Constructing Democracy in African Muslim Contexts." Comparative Politics 42(4), 375-393. Retrieved February 26, 2020, from www.jstor.org/stable/ 25741372

- (2013). "Negotiating Islam in the Era of Democracy." In Tolerance, Democracy, and Sufis in Senegal, (M. Diouf, Ed.). New York: Columbia University Press. DOI: 10.7312/columbia/ 9780231162630.001 .0001

Waldner, D. and E. Lust (2018). "Unwelcome Change: Coming to Terms with Democratic Backsliding." Annual Review of Political Science 21(May), 93-113.

Newspapers Articles and Online Resources

Arab Barometer

- Arab Barometer V - Tunisia Country Report 2019 (https://www.arabbarometer.org/wpcontent/uploads/ABV Tunisia Report Public-Opinion 2018-2019.pdf)

Financial Times

- "Democracy Hangs in the Balance in Tunisia", Safwan Masri, 26 September 2019 (https://www.ft.com/content/7db6ae96-dfac-11e9-b8e0-026e07cbe5b4 last accessed Dec 17, 2019)

The New York Times

- "The Future of Democracy in Tunisia", Rory McCarthy, 24 September 2019 (https://www.nytimes.com/2019/09/24/opinion/tunisia-democracy.html last accessed Dec 17, 2019)

Tunisian Constitution

- 2014 Tunisian Constitution (https://www.constituteproject.org/constitution/Tunisia 2014.pdf last accessed July 14, 2020) 